\title{
PERIMENOPAUSAL STRESS REACTIONS: A QUALITATIVE STUDY ON THE AWARENESS OF SPOUSES
}

\author{
Ammu G Nair \\ https://orcid.org/0000-0002-1243-5154 \\ ammu122@gmail.com \\ University of Kerala, India \\ Sonia George \\ https://orcid.org/0000-0001-9313-7636 \\ soniageorge@gcwtvm.ac.in \\ University of Kerala, India
}

Received April 18, 2021; Revised May 26, 2021; Accepted June 2, 2021

\begin{abstract}
The menopausal transition can be a period of stress, even lead to trauma if left unnoticed or unsupported. Perimenopause is considered to be the period (3-8 years) before and after the final menstrual cycle. It is a phase in a woman's life that needs immense support and care from the spouse. But still, researchers are skeptical about the information men have regarding the period. Even though many studies highlight the physiological changes that happen during the perimenopausal or menopausal transition period, there is still a lack in the number of studies that emphasize the psychological difficulties women face in the perimenopausal period. Emotional support from the husband is of significance amid many such difficulties. The study intends to investigate the level of awareness men have about the perimenopausal period.The study also tries understand how the spouses perceive themselves to have supported their wives during the perimenopausal period. The study followed a qualitative approach in data collection and analysis. The data was collected using a semi-structured interview. 34 men (spouses of perimenopausal women) from Thiruvananthapuram, Ernakulam, and Thrissur districts of Kerala, India were selected using purposive sampling. The method of thematic analysis was used to analyze the data. For the analysis, the software NVivo was used. The final themes extracted were unawareness, attitude, regret, and techniques to be adopted. The results revealed the unawareness majority of the participants had about the phase and throw light on the need to create awareness among men to help women cope better with the phase. The major reasons, the participants noted as reasons for their unawareness, were lack of information from the family, lack of communication from their spouses, which led to major confusion in them.
\end{abstract}

Keywords: menopause, perimenopause, women, spouse, awareness, communication.

Наїр Амму Г, Джордж Соня. Стресові реакції жінок під час перименопаузи: якісний аналіз усвідомлення проблеми чоловіками.

Анотація. Початок періоду менопаузи у жінки може бути стресовим, навіть призвести до травми, якщо його ігнорувати або якщо жінці не надавати необхідної підтримки. Перименопаузою вважають період (3-8 років) до і після завершального менструального циклу. Перименопауза - це етап у житті жінки, упродовж якого вона потребує підтримки та турботи з боку чоловіка. Водночас, дослідники скептично ставляться до інформації, якою володіють чоловіки про цей період. Незважаючи на те, що багато досліджень висвітлюють

(C) Nair, Ammu G; George, Sonia, 2021. This is an Open Access article distributed under the terms and conditions of the Creative Commons Attribution 4.0 International Licence (http://creativecommons.org/licenses/by/4.0).

East European Journal of Psycholinguistics, 8(1), 83-94. https://doi.org/10.29038/eejpl.2021.8.1.nai 
фізіологічні зміни, що відбуваються в перименопаузальний або менопаузальний перехідний період, все ще бракує досліджень, які акцентують увагу на психологічних труднощах, 3 якими стикаються жінки. Дослідження має на меті вивчити ступінь усвідомлення чоловіками проблеми перименопаузального періоду, а також з'ясувати, як чоловіки сприймають власну підтримку дружин у перименопаузальний період. У дослідженні взяло участь 34 чоловіка з районів Тіруванантапурам, Ернакулам та Тріссур штату Керала (Індія), у чиїх жінок був період перименопаузи. У дослідженні застосовувалися методи якісного аналізу даних, які були отриманні в результаті використання напівструктурованого інтерв'ю, зокрема метод тематичного аналізу із застосуванням програмного забезпечення NVivo. Було встановлено такі провідні теми у досліджуваних інтерв'ю: неусвідомленість проблеми, ставлення, жаль та можливі способи підтримки жінок. Результати дослідження засвідчили необізнаність більшості чоловіків щодо цього періоду життя жінок. Важливим прикладним аспектом дослідження є висновок про необхідність просвітницької роботи серед чоловіків, спрямованої на психологічну підтримку жінок, аби вони краще почувалися в цей період. Основними причинами низького усвідомлення проблеми, на думку чоловіків, $\epsilon$ відсутність інформації у родинах, в яких вони виховувалися, а також небажання дружин обговорювати цю проблему.

Ключові слова: менопауза, перименопауза, жінки, чоловіки, усвідомленість, спілкування.

\section{Introduction}

Menopause or the climacteric is the stage in a woman's life when the monthly menstrual cycle ceases. The arduous phase that the individual endures before she reaches menopause is called perimenopause. Perimenopause is a period of physical and mental change. Support from the life partner is of great significance during any period in an individual's life. Though it is highly acclaimed when it comes to menstruation, it is skeptical about how important spouse support has been considered during menopause and the menopausal transition period. A phase of struggle and chaos for most, which, with constant support from the spouse could be made endurable, at the same time traumatize the victim if unsupported. Biological science and Psychology say about the change that can be brought in when women experience the luxury of having their spouses besides them, especially with emotional support (Bahri et al., 2016). It can be specifically said as a "luxury", as the number of women lacking effective assistance is high (Hassan et al., 2020). Especially in India, menopause is a topic that is very rarely talked about. Women living through it, most often, are seen bearing it alone, without appropriate knowledge or efficiency. The ignorance many times leads to a high level of stress and tension. The testimonials of many, reported by psychologists and other doctors reveals that they have all underwent the midlife trauma of perimenopause, which led them later towards a period of post-traumatic stress disorder. Many failed in doing any self-care nor did she get any help from their spouses. These led to a severe span of trauma. The relevance of care during the phase implies here and it, to a large extent relies upon the awareness of the individual and spouse too.

The study intended to explore the awareness, to what extend supported their wives and how concerned they were in offering scare to their wives. The large 
number of studies done on the area, vividly show how beneficial the support is in alleviating the symptoms (Kalahroudi, 2013)

The number of studies that investigated the various aspects of the perimenopausal period from a deeper perspective is innumerable. The studies on spouses of perimenopausal women are yet to get their relevance in India, even though many western studies have already mentioned the importance of spouse awareness and support during the menopausal transition. The study by Mansfield (2003) revealed that one-third of the participants (husbands of perimenopausal women) reported being unsupportive. And it is something to be noted how most of them were not informed about the phase and knew very little information that they got from their wives. A study conducted on 450 men who lived with perimenopausal wives revealed the need of enhancing the awareness among men about the phase and how it would help women cope better with the situation (Parish et al., 2019). Providing adequate information and educating the husbands has been found to have a significant positive impact on the menopausal health of their partners (Yoshany et al., 2017).

The increasing life expectancy rate, duties, responsibilities, and changing lifestyles, are all making it a necessity to study the 'transition phase' in a deeper aspect and find effective ways with which it can be handled well. As per many studies, spousal support is found as one of the most important factors that help perimenopausal women in alleviating the symptoms (Bahri et al., 2016; Mansfield et al., 2003). But still, a lack of awareness is seen in many (Hidiroglu et al., 2014). Being aware and knowing about the phase is incredibly important in making effective management plans.

Hypothesis: There is significantly less awareness among spouse regarding the perimenopausal period.

\section{Method}

The study followed a qualitative method of research. The responses from the spouses were collected using a semi-structured interview method. Thematic analysis strategy using NVivo software was employed to analyze the responses to reach the results.

\section{Sample}

The sample consisted of 34 men, selected using the purposive sampling method from the districts of Kerala, India. The inclusion critieria was strictly filtered for men, whose wives were presently undergoing the perimenopausal period. The following questions were used to elicit response from participants as part of the semi-structured interview:

1. Are you familiar with the terms menopause and perimenopause?

2. What do you think are the problems women face during the perimenopausal period? 
3. How all can husbands help women during the phase?

4. How much do you think you have helped your wife during the period

5 . Do you think you could have helped her better?

6. If yes, how?

\section{Results and Discussion}

\section{Major codes identified}

The following are the major codes identified as a result of the thematic analysis

1. Unawareness

2. Regret

3. Attitude (positive, negative, mixed, and neutral)

4. Techniques

5. Confusion

6. Lack of support

7. Information from the family

8. Lack of communication

9. Priorities

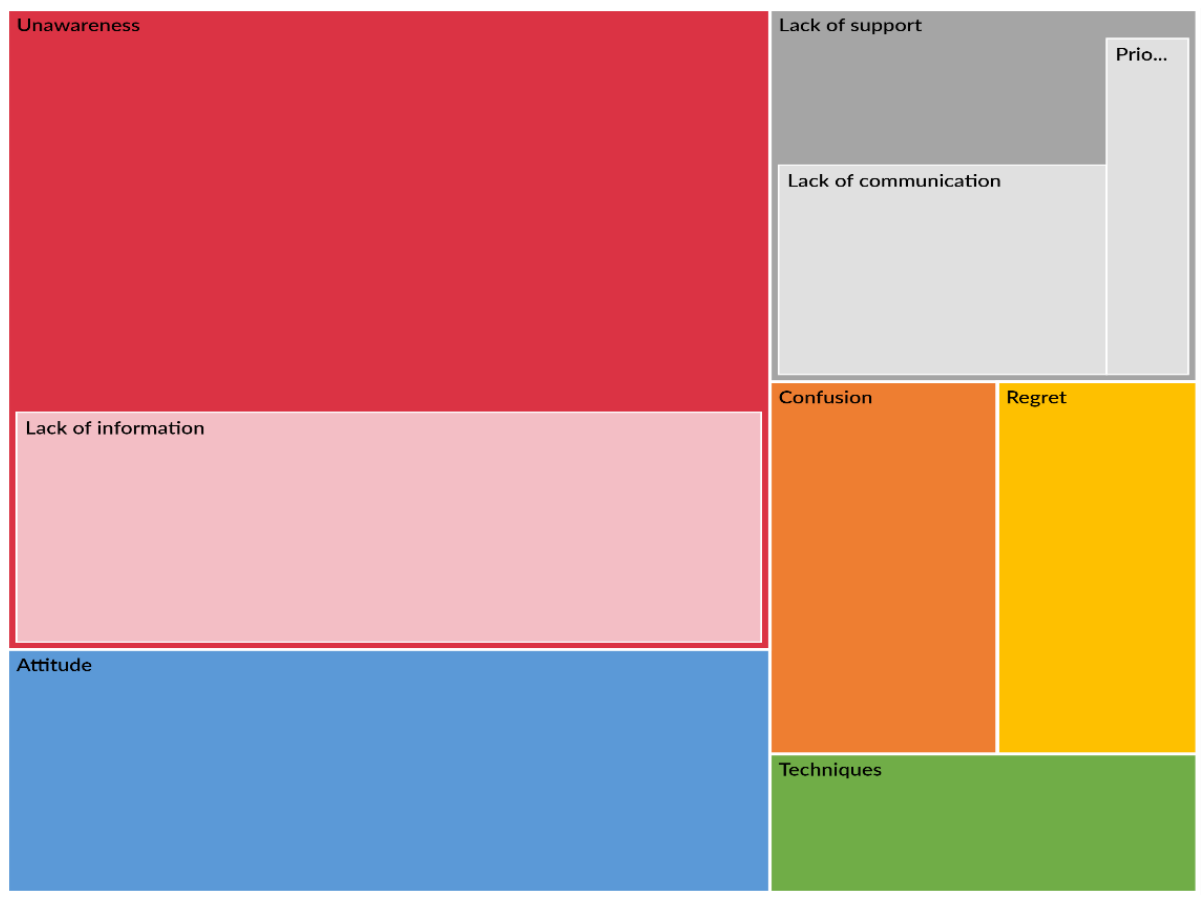

Figure 1. Depicting the hierarchy chart of the codes.

Some of the codes were merged as they showed similarity or overlapped. The six final codes extracted are mentioned below.

1. Unawareness

2. Attitudes

3. Techniques 
4. Lack of communication

5. Regret

6. Confusion

Finally, the codes were categorized under four themes such as unawareness, attitude, regret, and techniques to be adopted.

\section{Unawareness}

It was found that most of the participants were not aware of the menopausal transition period or the perimenopausal period. The major reasons found were lack of information from the family, lack of communication, and confusions due to these two.
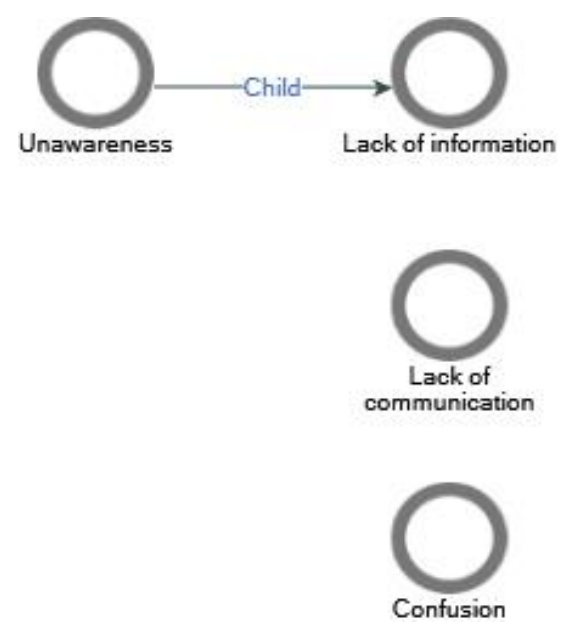

Figure 2. Depicting the theme unawareness and the child themes.

29 participants out of 34 reported that they are not aware of the perimenopausal period and the difficulties faced during the menopausal transition. 5 participants who said that they were aware of the period belonged to medical or allied professions, who were approached by patients with menopausal issues. But the irresoluteness about their role in managing wives' menopausal issues was dismaying. Here, the possession of information may be taken in as futile if not brought into use. The situation demands an investigation to examine the reasons for this high level of unawareness.

The result encapsulates unawareness as to the product of lack of information (from the family, from the society), lack of communication (with mother, sisters, friends, wife), and confusions regarding the phase. Confusions might also be comprehended as a product of the first two factors.

From literature, it can be understood that, till of late most of the boys were brought up with minimal exposure to the biological/developmental changes in girls. Studies showed curiosity in understanding how boys and men responded to researchers' queries about their knowledge about menstruation and menopause. The responses revealed how their information was limited solely to the curriculum, 
which made them unaware of the difficulties encountered by their friends, sisters, or mother during that period. Boys believed in keeping themselves aloof from all these due to cultural demands, at the same time wanted to support their sisters and friends (Gundi \& Subramanyam, 2020). Studies also report how they were doubtful about getting involved in such matters thinking about the consequences it might bring (Mason et al., 2017). Gender role stereotyping too might have held them away from such topics. Theorists also support the fact that during adolescence the gender intensification process happens (Santrock, 2019). The adolescents thrive to conform to their socially accepted and conventional gender roles. Hence, how the conventional gender roles find credence among boys and how they carry it forwards throughout their lives are clear. Culture and tradition play a crucial role here.

Studies also found that the boys were keen on gaining knowledge through many sources other than family. Here, the relevance of sharing information arises, where the credibility or authenticity of the source that they are relying on is at stake (Gundi \& Subramanyam, 2020). Would not it be incredibly helpful if males receive the information from their mothers or sisters? Which would cater to reducing confusion and enhance the probability of them helping in need.

This insufficient information shows its effect in the middle age too and keeps men aloof from the toil borne alone by women. Hence, it is cleared up how the exposure to such matters develops into unawareness. And uncovers the importance of making them familiar with such matters right from an early stage.

One concern the participants put up was the unreadiness of their wives to communicate the problems. The divulgence made the infuriation in husbands clear to the researcher. Husbands' expectation of an objective expression of the concerns was never fulfilled. They reported indignant displeasure in their wives' expectation of understanding things that were not communicated to them.

Some of the few factors to this may be discussed here. One, the gender difference in the ability to observe and understand nonverbal signs of the other. Second, the proficiency or higher capability of women in taking care of fellow beings in need. And third, the upbringing in our culture.

The ineptitude of men in acknowledging the minute changes in their partners as opposed to women has been brought up in many studies (Jaušovec \& Jaušovec, 2009). Women's higher proficiency in visual event learning, reacting, and categorizing than men, was primarily discussed in the study by Tannen (Tannen, 1990). The study also discussed the difference in the way both genders found and executed communication. The theory of rapport talk, and report talk differentiates the way both genders communicate. When females are more interested in rapport talking wherein, they establish relationships, men are more interested in engaging in report talk, which meets the exchange of information (Santrock, 2019). In the present study also, during the interviews, it was found that the participants showed eagerness if issues were conveyed objectively, which women failed to. This probably might have made women hesitant, out of the feeling that the messages conveyed did not create the intended impression on their husbands. But evidence reveals inefficient communication due to the above-mentioned reasons, along with 
the lack of knowledge and difference in attitude. The studies on psycholinguists too denote gender difference as one of the major factors in communication and perceptions of certain concepts. The study by Wahyuningsih (2018) mentions the gender difference in understanding and comprehending language and even the way each gender uses language. When men use more directive language, women were more interested in using non-directive and expressive language (Wahyuningsih, 2018). This too might be considered as one of the major factors leading to the dearth of communication.

On to the third factor, the societal makeup and upbringing, which is not easy to be altered overnight. Our system, which considers it highly worthy of suppressing such matters all to oneself, might have made women dubious to divulge their menopausal problems even to their partners. Studies that throw light on the importance of spousal communication, postulates the lack in the same, leading to increased distress and difficulty in women (Taebi et al., 2018).

Considering these as the engendering factors to the theme 'unawareness', awareness should not be an adjunct in alleviating the menopausal issues, rather one of the most important factors which could help women cope with it effectively with spousal support.

\section{Attitudes}

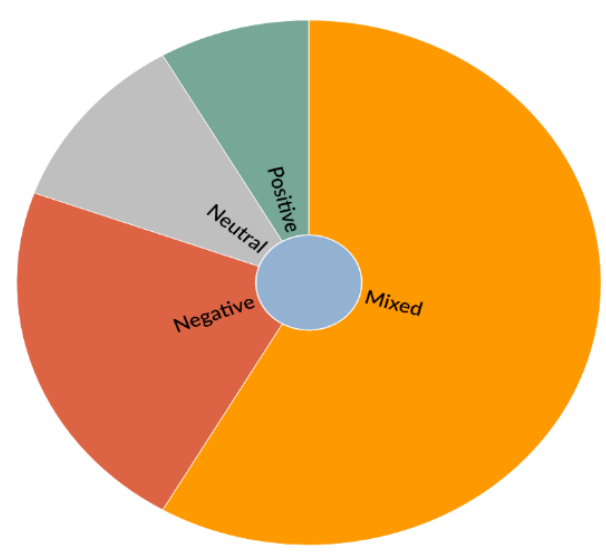

Figure 3. The hierarchy chart of the attitudes of the participants towards the perimenopausal period.

The chart shows the nominal number of responses with a positive attitude towards the menopausal transition phase. Most of them have responded with a mixed attitude, which communicated an uncertainty or confusion the participants had.

Attitude in psychology has been described as the "readiness of the psyche to act or react in a certain way" by Carl Jung (Main, 2004). As per Ajzen, attitudes are considered as a "complex and acquired state through experiences" (Perloff, 2020). Researchers who were interested in the attitude-behavior relationship have always 
noted the importance of family and society. Every individual majorly develops their attitude towards a person, concept, event, or phenomenon depending on the inputs they receive from their family and the society that they live in. As it has been already noted above that the traditional backdrop shows how irrelevant it was to even converse about menopause and menarche in Indian households until a few years back, it should not surprise anyone if the men in mid-age do not bear a much positive attitude towards menopause. People cannot be expected to haul something with so much effort which was not revealed before them since years. The theory of Reasoned Action by Ajzen has put forward the attitude-behavior relationship (Ajzen $\&$ Fishbein, 1980). He says that human beings always tend to behave according to the attitudes they have gained from their experiences of so many years of life. The attitudes men have acquired from the family and society have pulled them from heading their way into having a positive outlook towards the perimenopausal phase. As per the affective-cognitive theory of attitude, attitudes are the byproducts of information too (Rosenberg, 1956). Attitude gains a positive note when a person is enriched with information on a topic, or event. And the opposite happens when the knowledge is less. Here, one of the major reasons for husbands having a negative attitude may be understood, as an effect of unawareness or lack of proper knowledge.

A few of the participants showed a mixed attitude too. Normally attitudes are considered as positive or negative. Here, a few held the view that perimenopause could bring in changes, at the same time they were doubtful about the manifestation of those changes. The analysis hence resulted in showing a mixed attitude. The reluctance to open up, minimal knowledge, readiness to learn more, slowly starting to understand the difficulty, the embarrassment of having mistaken the phase as easy, might be some of the few reasons. Many showed the readiness to know more, but presently they are blank. Responses like "Yes, I guess it might be difficult", "would that be so much difficult", "never knew, maybe" could be categorized under mixed attitudes. Many of the participants possessed negative attitudes only because they lacked proper information. Now that social media and the virtual world have become so wide that women are raising their voices with confidence.

Men today, are exposed to all the posts, videos, and write-ups. Attitude theories have said that, unlike personality, attitudes are subject to change by experience. More the exposure towards the menopausal transition the more can be the development of a favorable attitude. Zajonc (1968) proposed a concept called the "Mere-exposure effect" (repeated exposure effect), in which he said that people tend to develop a more and more positive attitude towards a particular phenomenon/event when he/she is continuously exposed to it than if they are not (Zajonc, 1968). In the case of the participants also the researcher could see the mere exposure effect when they were ready to incorporate more positivity to the negativity they showed in the beginning. But some continued to possess a negative attitude. They were very adamant in their views and strongly believed that women make up all these problems to just gain attention. They were quite unempathetic in their approach. The personality of such participants might be subjected to further research. As all studies 
suggest a positive attitude and support from the husband, women find it easier to manage the problems (Mansfield et al., 2003; Zhang et al., 2020).

\section{Regret-failed in offering support}

a. Lack of support

b. Other priorities

The majority of the participants readily opened up and said they repent for not having supported their wives when needed. The major reasons put forward were unawareness and priorities. Most of them opinioned that they prioritized many other responsibilities above this and now repent that they did so. It should not be discounted that people go through so many duties and responsibilities in daily life. It cannot be expected from anyone to sit with their wife 24/7 leaving all other works. But practically it is possible to spend some quality time during which she experiences the warmth and support. Some even said that they are supporting their wives in the ways they know. Mainly giving them a day off from household duties, letting them take rest not asking them to clean. But such strategies were found to be ineffective according to the participants. The respondents were unhappy that their good intentions went unnoticed. Wives did not appreciate those. Here, the difference between received support and perceived support could be noticed. Uchino (2009) differentiated these two types of support systems. In the former one, people offer support, but unfortunately, the receiver does not feel supported. Whereas in the latter one, there is a subjective sense of support being felt, that someone is there to care and listen to them. If the person in need does not feel the warmth, then the strategy goes futile. The ineffective execution was found as one of the major issues here. Husbands were found to have failed in offering emotional support which is essential for the overall well-being and health (Burleson, 2003).

The majority (30 out of 34 ) of the participants revealed their priorities, which largely focused on work and children. They repented taking their wives for granted. The expectation that their wives kept up with health like past years, misled them and failed to notice the changes. This regret also might have led them not to accept the phase completely and give a mixed opinion. Only a very few showed the readiness to find ways to make the situation better. As the regret theory by Graham Loomes (1982) proposed, people tend to anticipate regret and try all possible ways to avoid that. They fail to acknowledge the regret and seek ways out of it (Loomes \& Sugden, 1982).

\section{Techniques to be adopted}

10 participants out of 34 believed they need information about several techniques that can be adopted to understand and manage perimenopausal problems. All of them said that they wanted more information about the phase from experts, preferred to visit one much before the symptoms worsen to an unmanageable state.

These responses too may be explained on the grounds of the regret theory. It may be assumed that those participants might have anticipated the regret later in life 
if they do not try effective ways to reduce their wives' disturbing perimenopausal symptoms. They would have preferred to avoid the confusions that might worsen the difficulty. For that, they showed the readiness to get help from a professional who can guide them through the phase, which indeed was an incredibly positive sign.

\section{Conclusions}

From all the responses, the themes identified could be clearly defined by many socio-cultural and personality factors. Lack of awareness, the differences in the ways things are communicated, cultural backdrop, all these lay the stone for the behavior men have towards perimenopausal women. A large part of women's life is spent in active participation in developing other's lives, unlike men. And women get worried if they fail in satisfying this role, which is not seen in men (Baker, 2012). This gender difference plays a particularly important role in the symptom experience, manifestation, and management of the perimenopausal symptom. Culture, as psychology defines, the behavior patterns, beliefs, and all other products of a group of people that are passed on from generation to generation, plays a major role. And most people tend to believe that our group and its beliefs are superior to that of others. The ingroup bias is a very strong constituent that contributes to the attitudes and finally to the behavior of humans. The cultural differences do play a very crucial role in the perception and behavior of both men and women in the present study context. The study is a pointer towards the ineffective information boys receive from their families regarding such delicate needs of women, which manifests as problems later in their lives. It is high time that this rearing pattern changes and boys/men understand the physical changes in women which leads to many mental disturbances. The responses and results disclose the major need of effective communication between the spouses that can resolve much of the problems. Awareness creation about the phase and awareness on effective communication can be thought of as two major techniques that could be adopted to enhance support and alleviate the symptoms.

Mental and other health professionals have a major role in the context wherein, reliable, and authentic information can be passed. In that way, a lot of women can be supported in recovering, overcoming, and managing a difficult phase that could be difficult or even traumatizing for several women. Psychologists and other health professionals need to understand their role in creating awareness among men about menopause and perimenopause. All the techniques adopted, together, will lead to a future with happy perimenopausal women whose journey through the period will be easy and relaxing.

\section{References}

Abedzadeh Kalahroudi, M. (2013). Strategies for improvement quality of life in menopause. Nursing and Midwifery Studies, 1(4), 240-241. https://doi.org/10.5812/nms.10819 
Ajzen, I., \& Fishbein, M. (1980). Understanding attitudes and predicting social behavior. PrenticeHall.

Bahri, N., Yoshany, N., Morowatisharifabad, M. A., Noghabi, A. D., \& Sajjadi, M. (2016). The effects of menopausal health training for spouses on women's quality of life during menopause transitional period. Menopause, 23(2), 183-188. https://doi.org/10.1097/GME.0000000000000588

Baker, J. M (2012). Toward a New Psychology of Women. (2nd ed.). Beacon Press.

Burleson, B. R. (2003). The experience and effects of emotional support: What the study of cultural and gender differences can tell us about close relationships, emotion, and interpersonal communication. Personal Relationships, 10(1), 1-23. https://doi.org/10.1111/1475-6811.00033

Gundi, M., \& Subramanyam, M. A. (2020). Curious eyes and awkward smiles: Menstruation and adolescent boys in India. Journal of Adolescence, 85, 80-95. https://doi.org/10.1016/j.adolescence.2020.09.013

Hassan, I. I., Hazlina, N., Hussain, N., Sulaiman, Z., Kadir, A. A., Zarawi, M., \& Nor, M. (2020). Menopausal women's experiences of husband's support: A negative view. Enfermia Clinica, 30(S2), 190-193. https://doi.org/10.1016/j.enfcli.2019.07.075

Hidiroglu, S., Tanriover, O., Ay, P., \& Karavus, M. (2014). A qualitative study on menopause described from the man's perspective. Journal of Pakistan Medical Association, 64(9), 10311036.

Jaušovec, N., \& Jaušovec, K. (2009). Do women see things differently than men do? NeuroImage, 45(1), 198-207. https://doi.org/10.1016/j.neuroimage.2008.11.013

Loomes, G., \& Sugden, R. (1982). Regret theory: an alternative theory of rational choice under uncertainty. The Economic Journal, 92(368), 805. https://doi.org/10.2307/2232669

Main, R. (2004). The Rupture of Time: Synchronicity and Jung's Critique of Modern Western Culture. Routledge.

Mansfield, P. K., Barthalow Koch, P., \& Gierach, G. (2003). Husbands' support of their perimenopausal wives. Women and Health, 38(3), 97-112.

https://doi.org/10.1300/J013v38n03_07

Mason, L., Sivakami, M., Thakur, H., Kakade, N., Beauman, A., Alexander, K. T., van Eijke, A. M., Laserson, K. F., Thakkar, M. B., \& Phillips-Howard, P. A. (2017). "We do not know": a qualitative study exploring boys perceptions of menstruation in India. Reproductive Health, 14(1), 174. https://doi.org/10.1186/s12978-017-0435-X

Parish, S. J., Faubion, S. S., Weinberg, M., Bernick, B., \& Mirkin, S. (2019). The MATE survey: Men's perceptions and attitudes towards menopause and their role in partners' menopausal transition. Menopause, 26(10), 1110-1116. https://doi.org/10.1097/GME.0000000000001373

Perloff M, R. (2020). The Dynamics of Persuasion: Communication and Attitudes in the Twenty-First Century. Routledge.

Rosenberg, M. J. (1956). Cognitive structure and attitudinal affect. Journal of Abnormal and Social Psychology, 53(3), 367-372. https://doi.org/10.1037/h0044579

Santrock, J. (2019). Adolescence (17th ed.). McGraw Hill Education.

Taebi, M., Abdolahian, S., Ozgoli, G., Ebadi, A., \& Kariman, N. (2018). Strategies to improve menopausal quality of life: A systematic review. Journal of Education and Health Promotion, 7(1), 93. https://doi.org/10.4103/jehp.jehp_137_17

Tannen, D. (1990). You Just Don't Understand. N.Y.: Ballantine Books.

Uchino, B. N. (2009). Understanding the links between social support and physical health: a life-span perspective with emphasis on the separability of perceived and received support. Perspectives on Psychological Science: A Journal of the Association for Psychological Science, 4(3), 236-255. https://doi.org/10.1111/j.1745-6924.2009.01122.x

Wahyuningsih, S. (2018). Men and women differences in using language: a case study of students at stain kudus. EduLite: Journal of English Education, Literature and Culture, 3(1), 79. https://doi.org/10.30659/e.3.1.79-90 
Yoshany, N., Morowatisharifabad, M. A., Mihanpour, H., Bahri, N., \& Jadgal, K. M. (2017). The effect of husbands' education regarding menopausal health on marital satisfaction of their wives. Journal of Menopausal Medicine, 23(1), 15. https://doi.org/10.6118/jmm.2017.23.1.15

Zajonc, R. B. (1968). Attitudinal effects of mere exposure. Journal of Personality and Social Psychology, 9(2 PART 2), 1-27. https://doi.org/10.1037/h0025848

Zhang, X., Wang, G., Wang, H., Wang, X., Ji, T., Hou, D., Wu, J., Sun, J., \& Zhu, B. (2020). Spouses' perceptions of and attitudes toward female menopause: a mixed-methods systematic review. Climacteric, 2(23), 148-157. https://doi.org/10.1080/13697137.2019.1703937. 